\title{
Why bacteria are smaller in the epilimnion than in the hypolimnion? A hypothesis comparing temperate and tropical lakes
}

\author{
J. Salvador HERNÁNDEZ-AVILÉS, Roberto BERTONI, ${ }^{1}$ Miroslav MACEK, ${ }^{2}$ and Cristiana CALLIERI ${ }^{1 *}$ \\ UNAM, FES Zaragoza, Dpt. of Limnology, Av. Guelatao 66, 09230 Iztapalapa, D.F. Mexico; ${ }^{1}$ CNR - Institute of Ecosystem Study, \\ Largo Tonolli 50, 28922 Verbania, Italy; ${ }^{2}$ NNAM, FES Iztacala, Dpt. of Tropical Limnology, Av. De los Barrios 1, 54090 Tlalnepantla, \\ Edo. México, Mexico \\ *Corresponding author: c.callieri@ise.cnr.it
}

\begin{abstract}
Bacterial size and morphology are controlled by several factors including predation, viral lysis, UV radiation, and inorganic nutrients. We observed that bacterial biovolume from the hypolimnion of two oligotrophic lakes is larger than that of bacteria living in the layer from surface to $20 \mathrm{~m}$, roughly corresponding to the euphotic/epilimnetic zone. One lake is located in the temperate region at low altitude (Lake Maggiore, Northern Italy) and the other in the tropical region at high altitude (Lake Alchichica, Mexico). The two lakes differ in oxygen, phosphorus and nitrogen concentrations and in the temperature of water column. If we consider the two lakes separately, we risk reducing the explanation of bacterial size variation in the water column to merely regional factors. Comparing the two lakes, can we gather a more general explanation for bacterial biovolume variation. The results showed that small bacteria dominate in the oxygenated, P-limited epilimnetic waters of both lakes, whereas larger cells are more typical of hypolimnetic waters where phosphorus and nitrogen are not limiting. Indeed, temperature per se cannot be invoked as an important factor explaining the different bacterial size in the two zones. Without excluding the top-down control mechanism of bacterial size, our data suggest that the average lower size of bacterial cells in the epilimnion of oligotrophic lakes is controlled by outcompetition over the larger cells at limiting nutrients.
\end{abstract}

Key words: bacterial size, bacteria in hypolimnion, Lake Maggiore, Lake Alchichica.

Received: October 2011. Accepted: December 2011.

\section{INTRODUCTION}

The heterotrophic bacterial community is the most important biological component in the transformation and mineralization of organic matter in aquatic systems, and its biomass constitutes a large fraction of the total plankton biomass (Simon et al. 1992). It is recognized that bacteria mediate key pathways in biogeochemical cycles (Sherr, and Sherr 2000) and are also the main food source for microorganisms at the base of the food web (Azam et al. 1983).

Among the characteristics of aquatic bacterial assemblages, cell size firstly attracted the attention of investigators (Stevenson 1978). Direct epifluorescence microscopy of DAPI (4',6-diamidino-2-phenylindole) stained samples has been successfully used as standard method for bacteria counting and sizing in the last decades (Porter, and Feig 1980). In the early 1990s, flow cytometry was introduced as an effective and rapid method for bacteria counting (Shapiro 1995) and rapidly became a key tool in aquatic microbial ecology. Nevertheless, microscope counting, although time-consuming, is less expensive and allows for a direct view of the cells. The relationship among side scatter, DAPI fluorescence and cell volume measured by epifluorescence microscopy (Robertson, and Button 1989; Gasol, and del Giorgio 2000; Felip et al. 2007) allows to compare bacterial cell size obtained by flow cytometry (LNA and HNA cells) to cell size provided by microscopy (Button et al. 1996). In general and for the purpose of this paper, small cell volume came to be associated to low-nucleic acid (LNA) bacteria, while large cell volume to highnucleic acid (HNA) bacteria (Gasol et al. 1999; Lebaron et al. 2001).

Earlier, small bacteria have been considered dormant (Gasol et al. 1995). Nevertheless, while small bacteria have an ATP-per cell content 10-fold lower than large bacteria, once this is normalized to cell volume, the ATP/ biovolume rate is quite similar for small and large bacteria, thus demonstrating that both are active (Wang et al. 2009). Thus, the evidence from the analysis of cytometric parameters is contradictory and does not univocally account for the bimodal distribution of bacterial size both as to community activity and composition (Bouvier et al. 2007).

Bacterial size, structure, and morphology in the vertical profile can depend on many factors, like predation (Jürgens, and Matz 2002; Pernthaler 2005), viral lysis (Weinbauer, and Höfle 1998; Berdjeb et al. 2011), UV radiation (Corno et al. 2009), and organic and inorganic nutrients (Vrede et al. 2002). The top-down control mechanism indicates that protistan grazing mainly eliminates medium-sized bacterial cells, thus shifting the size- 

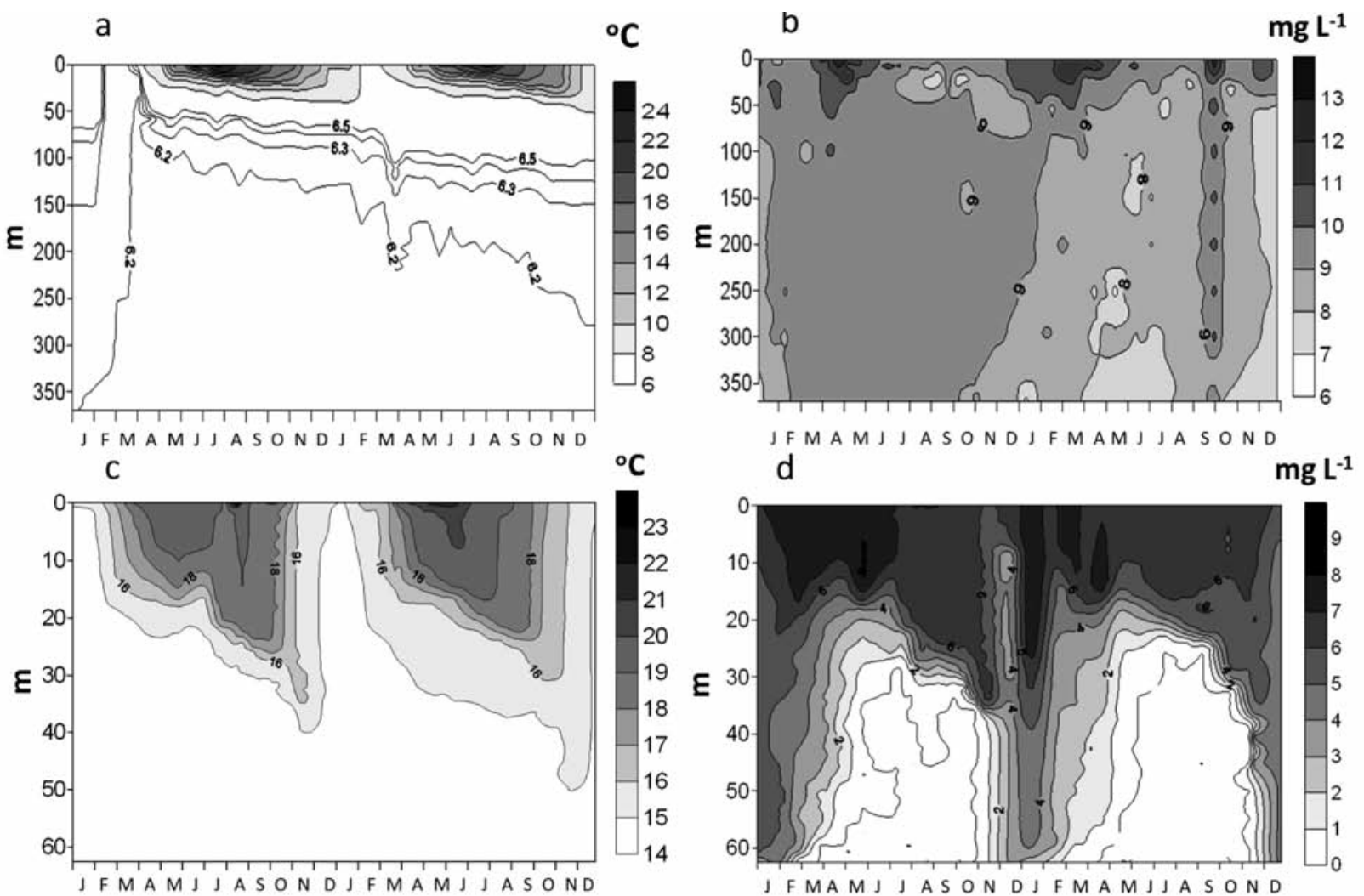

Fig. 1. Depth-time diagrams of isotherms and isopleths of dissolved oxygen concentration in Lake Maggiore (a and b) and in Lake Alchichica (c and d), during 2006 and 2007.

structure of bacterial assemblages towards smaller and/or larger cells (Hahn, and Höfle 1999). Therefore, grazing pressure may be indicated as an important cause of bacteria size variation over the year, strictly related to the presence of protozoa.

Less evident is the bottom-up control mechanism on bacterial size structure. In order to analyze this mechanism, in this paper we tried to clarify mainly the effects of physicochemical parameters on bacteria size, not considering the top-down effects.

Lakes have mixing and stratification periods throughout the year, according to their thermal pattern. During the thermal stratification gradients of dissolved oxygen and nutrient concentrations are established, which influence the vertical distribution of planktonic organisms. In particular, bacterial cell size in inland waters can fluctuate with depth and time, depending on the characteristics and dynamics of the system.

The presence of bacteria with larger mean size in the hypolimnion (20-350 m) and with smaller size in the epilimnion (0-20 m) was observed in the deep subalpine oligotrophic Lake Maggiore (Northern Italy) (Bertoni et al. 2010). In the present paper we enlarged our data set considering two-year data of bacteria cell size, temperature, oxygen, nitrogen and phosphorus in two oligotrophic lakes, one temperate (Lake Maggiore) and the other tropical (Lake Alchichica). The aim of this study was to determine if physicochemical parameters could affect the bacterial size patterns in the epilimnion and hypolimnion of the two lakes. We expected new insight for understanding cell size differences from the comparison of two water bodies which differ in many limnological features.

\section{MATERIALS AND METHODS}

Study sites

Lake Maggiore is a large, deep, subalpine, glacial lake $\left(212.2 \mathrm{~km}^{2}, Z_{\max } 372 \mathrm{~m}\right)$ (de Bernardi et al. 1996), located in a temperate area $\left(45^{\circ} 57^{\prime} \mathrm{N}\right.$ and $\left.8^{\circ} 38^{\prime} \mathrm{E}\right)$ at a low altitude (198 $\mathrm{m}$ a.s.1) within an exoreic basin with 13 main tributaries in Northern Italy. The lake is classified as holooligomictic, since complete overturn only takes place during strong wind and low air temperature periods, but the hypolimnion is always oxic (Ambrosetti et al. 2003) (Fig. 1). The lake is oligotrophic, with mean total chlorophyll- $a$ concentration of $2 \mu \mathrm{g} \mathrm{L}^{-1}$ (Bertoni et al. 2010) and TP of about $10 \mu \mathrm{g} \mathrm{L}^{-1}$ (Bertoni et al. 2004). Total inorganic nitrogen is never limiting in the whole water column with nitrate as the dominant form. Other distinctive characteristics are shown in Tab. 1. 
Lake Alchichica is a small, relatively deep, maar crater lake $\left(2.3 \mathrm{~km}^{2}, Z_{\max } 62 \mathrm{~m}\right)$ (Filonov et al. 2006), located in a tropical region $\left(19^{\circ} 24^{\prime} \mathrm{N}\right.$ and $\left.97^{\circ} 24^{\prime} \mathrm{W}\right)$ in a high-altitude plateau (2340 $\mathrm{m}$ a.s.l.) within the endorheic Oriental Basin of Central Mexico. It is classified as warm-monomictic as annual mixing takes place from late December to early March during the cold dry season. Lake Alchichica remains stratified throughout the rest of the year during the warm-rainy season (Alcocer et al. 2000). The lake is oligotrophic, with mean chlorophyll- $a$ concentration of 4 $\mu \mathrm{g} \mathrm{L}^{-1}$ (Adame et al. 2008). Inorganic nitrogen can be limiting in the epilimnion with ammonium as the dominant form (Macek et al. 2009) (Tab. 1).

\section{Samplings, chemical analyses}

In Lake Maggiore samples were collected monthly at the deepest point (Ghiffa: $372 \mathrm{~m}$ ) during 2006 and 2007. Water samples from epilimnion were taken using a sampler which collects a $5 \mathrm{~L}$ sample in a single operation from the thermocline depth up to the surface (Bertoni, pat. 96/A 000121). Samples from the hypolimnion were all taken at the thermocline depth, at $50 \mathrm{~m}$, and at $50 \mathrm{~m}$ intervals down to the bottom. The integrated sample was obtained by pooling volumes for each sample proportional to the thickness of the layer. Soluble Reactive Phosphorus (SRP) and Dissolved Inorganic Nitrogen (DIN) was determined according to A.P.H.A. (1992) after sample filtration through GF/C Whatman filters. Oxygen and temperature were measured in situ using a multiparameter submersible probe (Lake Maggiore: IDRONAUT OS316, Lake Alchichica: Hydrolab DS4/SVR4 Water Quality Monitoring System).

In Lake Alchichica samples were taken monthly throughout 2006 and 2007 using Niskin bottles. The sampling station was approximately in the centre of the water body, at the deepest part of the lake $(62 \mathrm{~m})$. Five depths were sampled at mixing and 10 depths during stratification, covering the surface $(0.5 \mathrm{~m})$, epilimnion, metalimnion and/or oxycline, hypolimnion, and near the bottom layers.
Tab. 1. Comparative characteristics of the temperate Lake Maggiore (Northern Italy) and the tropical Lake Alchichica (Central Mexico). Dissolved Oxygen (DO), chlorophyll- $a$ (chl- $a$ ), Particulate Organic Carbon (POC), Soluble Reactive Phosphorus (SRP), Dissolved Inorganic Nitrogen (DIN). (a) Bertoni et al. 2010, (b) Adame et al. 2008, (c) Alcocer et al. 2007.

\begin{tabular}{lcc}
\hline & Lake Maggiore & Lake Alchichica \\
\hline Trophic state & Oligo-trophic & Oligo-trophic \\
Salinity classification & Freshwater & Hyposaline \\
Thermal classification & Holo-oligomictic & Warm monomictic \\
Cold season & $6{ }^{\circ} \mathrm{C}$ & $14^{\circ} \mathrm{C}$ \\
Warm season & $6-24^{\circ} \mathrm{C}$ & $14-20^{\circ} \mathrm{C}$ \\
Oxygen at stratification & Oxigenated w.column & Anoxic hypolimnion \\
DO $\left(\mathrm{mg} \mathrm{L}^{-1}\right)$ & $5-4$ & $0-7$ \\
Mean chl- $a\left(\mu \mathrm{g} \mathrm{L}{ }^{-1}\right)$ & $2.0(\mathrm{a})$ & $4.2(\mathrm{~b})$ \\
POC $\left(\mu \mathrm{mol} \mathrm{L}^{-1}\right)$ & Epilimnion 20-26 (a) & Epilimnion 42-275 (c) \\
& Hypolimnion 5-8 (a) & Hypolimnion<8-167 (c) \\
SRP $\left(\mu \mathrm{g} \mathrm{L} \mathrm{L}^{-1}\right)$ & Epilimnion<1-8 & Epilimnion 4-16 \\
& Hypolimnion 6-10 & Hypolimnion 6-72 \\
DIN $\left(\mu \mathrm{g} \mathrm{L} \mathrm{L}^{-1}\right)$ & Epilimnion 631-880 & Epilimnion 12-40 \\
& Hypolimnion 840-895 & Hypolimnion 75-349 \\
\hline
\end{tabular}

Bacteria counting and biovolume measuring

In both lakes, samples for cell counting were immediately fixed with $0.2 \mu \mathrm{m}$ filtered formaldehyde (final concentration $2 \% \mathrm{vol} / \mathrm{vol}$ ) and the samples stored at $4{ }^{\circ} \mathrm{C}$ in the dark. After 4',6-diamidino-2-phenylindole (DAPI) staining (final concentration $0.1 \mu \mathrm{g} \mathrm{mL}^{-1}$ ), the samples were filtered onto $0.2 \mu \mathrm{m}$ pore-size polycar bonate membranes, and counted via epifluorescence microscopy (HBO $100 \mathrm{~W}$ lamp, 1250× and filter sets for UV: BP365, FT 395, LP420).

Bacteria morphometric measures (L:length, W:width) were obtained via images taken with a digital color camera (Cool Snap-Pro camera Media Cybernetics or Canon S45) and analyzed using image analysis software (Lake Maggiore: Image-Pro Plus 5.1 Media Cybernetics, Lake Alchichica: ImageJ). The volumes were estimated based
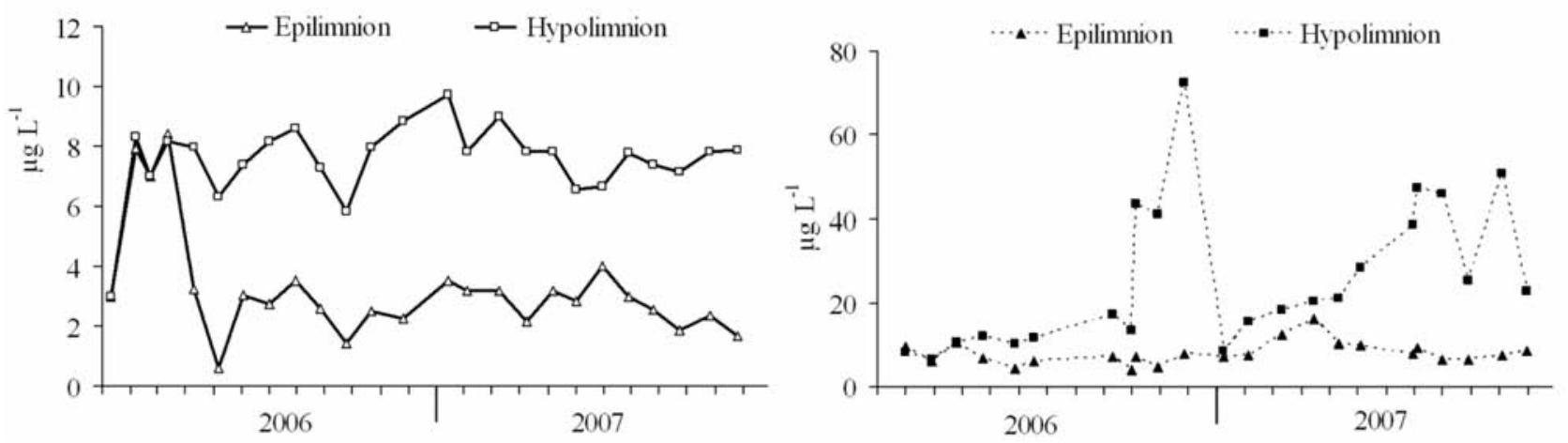

Fig. 2. Soluble Reactive Phosphorus (SRP) variations in the epilimnion and hypolimnion of Lake Maggiore (left panel) and Lake Alchichica (right panel) during 2006-2007. 
Tab. 2. Morphometric characteristics of bacterial cells in the epilimnion and hypolimnion of Lake Maggiore and Lake Alchichica (length $\mathrm{L}$, width $\mathrm{W}\left(\mu \mathrm{m}\right.$ cell $\left.^{-1}\right)$ and volume $\left(\mu \mathrm{m}^{3}\right.$ cell $\left.^{-1}\right)$ as annual mean \pm standard error).

\begin{tabular}{|c|c|c|c|c|c|c|c|}
\hline & Year & $\begin{array}{c}\text { Epilimnion } \\
\text { Length }\end{array}$ & Width & $\begin{array}{l}\text { Hypolimnion } \\
\text { Volume }\end{array}$ & Length & Width & Volume \\
\hline L. Maggiore & $\begin{array}{l}2006 \\
2007\end{array}$ & $\begin{array}{l}0.57 \pm 0.13 \\
0.67 \pm 0.16\end{array}$ & $\begin{array}{l}0.38 \pm 0.01 \\
0.46 \pm 0.01\end{array}$ & $\begin{array}{l}0.07 \pm 0.09 \\
0.12 \pm 0.16\end{array}$ & $\begin{array}{l}0.58 \pm 0.21 \\
0.80 \pm 0.26\end{array}$ & $\begin{array}{l}0.41 \pm 0.02 \\
0.53 \pm 0.03\end{array}$ & $\begin{array}{l}0.09 \pm 0.12 \\
0.18 \pm 0.23\end{array}$ \\
\hline L. Alchichica & $\begin{array}{l}2006 \\
2007\end{array}$ & $\begin{array}{l}0.93 \pm 0.21 \\
1.25 \pm 0.28\end{array}$ & $\begin{array}{l}0.22 \pm 0.04 \\
0.23 \pm 0.04\end{array}$ & $\begin{array}{l}0.04 \pm 0.01 \\
0.06 \pm 0.02\end{array}$ & $\begin{array}{l}0.99 \pm 0.23 \\
1.26 \pm 0.29\end{array}$ & $\begin{array}{l}0.24 \pm 0.02 \\
0.23 \pm 0.03\end{array}$ & $\begin{array}{l}0.05 \pm 0.03 \\
0.07 \pm 0.03\end{array}$ \\
\hline
\end{tabular}

on simple geometric shapes (bacteria as cylinder with two spherical ends) (Posch et al. 1997) and the systems calibrated with fluorescent latex beads ( $0.86 \mu \mathrm{m}$ diameter). Between 600 and 1000 cells were measured for each sample.

Statistical analysis was performed using Statgraphics plus analysis program Version 5, statistical package. Correlation was tested using the Pearson product moment correlation or Spearman Rank order correlation in case of not normally distributed data. Differences between the epilimnion and the hypolimnion were tested using $t$-test. The Mann-Whitney rank sum test was used when data were not-normally distributed. Data of bacterial cell biovolume were smoothed among sampling date using a simple moving average of 5 term-smoothing.

\section{RESULTS}

The depth-time diagrams of isotherms and dissolved oxygen isopleths clearly underline the contrast between tropical and temperate lakes (Fig. 1). While in Lake Maggiore dissolved oxygen (DO) is always present along the year in the deep hypolimnion, in Lake Alchichica DO shows different concentrations in the water column. The epilimnion is saturated or oversaturated, the metalimnion develops an oxycline related to the establishment of the termocline and the hypolimnion reaches a tendency to the anoxia. Soluble reactive phosphorus (SRP, Fig. 2) was significantly lower (Mann-Whitney rank sum test) in the epilimnion than in the hypolimnion both in Lake Maggiore $(n=25, p<0.001)$ and Lake Alchichica $(n=16$, $p<0.001$ ). Also DIN resulted significantly lower (MannWhitney rank sum test) in the epilimnion than in the hypolimnion in Lake Alchichica $(\mathrm{n}=16, p<0.001)$ and in Lake Maggiore $(\mathrm{n}=25, p<0.001)$, but in the latter this nutrient is never limiting production as the concentrations are always higher than $600 \mu \mathrm{g} \mathrm{L}^{-1}$.

Bacteria reach biovolumes lower than $0.2 \mu \mathrm{m}^{3}$ in Lake Maggiore and lower than $0.1 \mu^{3}$ in Lake Alchichica (Tab. 2). Comparing the same layers of the two lakes, cell biovolume in the epilimnion of Lake Maggiore was 1.6 fold larger than in Lake Alchichica and 2.4 fold larger considering the hypolimnion (Tab. 2). In general, the higher difference in bacterial cell size between epilimnion and hypolimnion appeared at higher water temperature. The presence of very small bacteria in Lake Alchichica

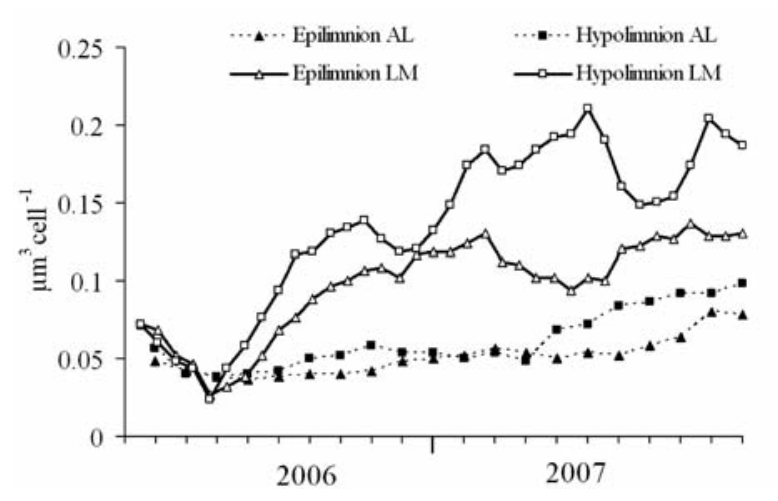

Fig. 3. Simple moving average of 5 term smoothing of bacterial cell biovolume in the epilimnion and hypolimnion of Lake Maggiore (LM) and Lake Alchichica (LA) during 2006-2007.
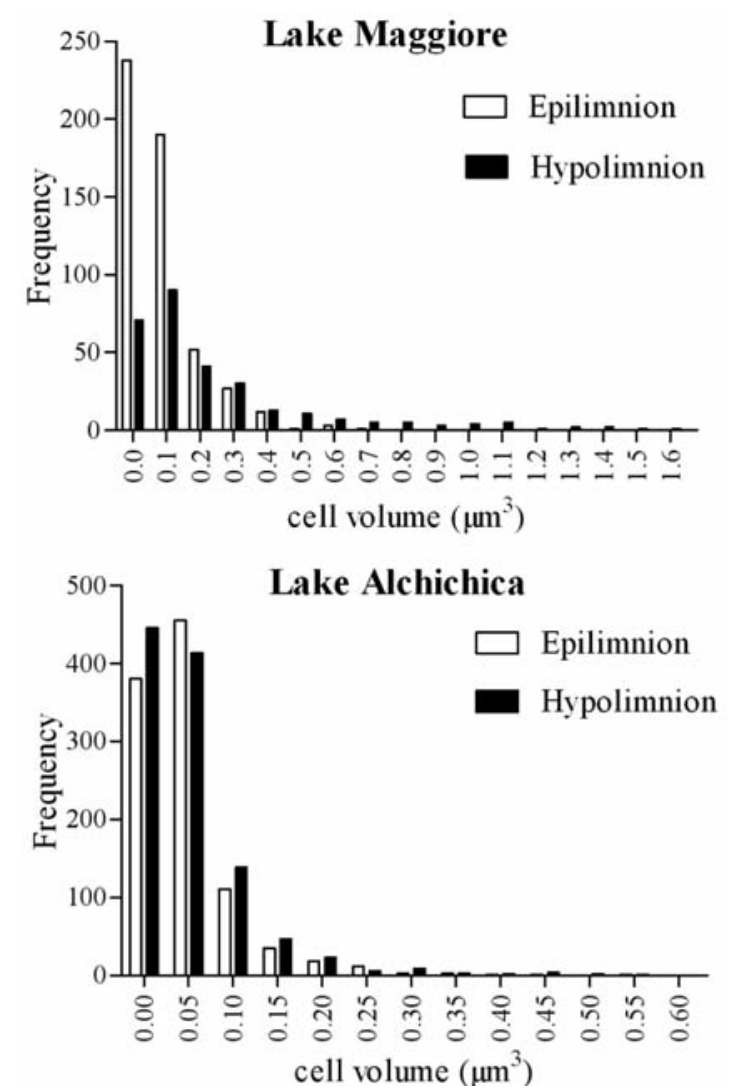

Fig. 4. Representative examples of bacterial volume frequency distribution in epilimnion and hypolimnion of Lake Maggiore and Lake Alchichica. 
(mean annual average: $0.04 \mu \mathrm{m} 3$ ) has been already underlined (Hernández-Avilés et al. 2010) but a difference along the vertical profile was never noted.

Analyzing two year smoothed data, we found that bacteria cell biovolumes in the hypolimnion were significantly larger than those in the epilimnion both in Lake Maggiore $\left(\mathrm{t}_{35}=3.73, \mathrm{p}<0.001\right)$ and Lake Alchichica $\left(\mathrm{t}_{19}=2.04, \mathrm{p}<0.05\right)$ (Fig. 3). The size frequency of bacterial volume in epilimnion and hypolimnion clearly show the different size of bacterial population in both lakes (Fig. 4).

In the stratification periods the differences were higher between these two zones, associated with the establishment of stratification in both lakes. In the anoxic hypolimnion cell biovolumes were 1.3 times larger than in the oxic epilimnion in Lake Alchichica, while in the oxygenated Lake Maggiore this ratio was 1.5.

In both lakes bacterial morphology was quite different. In Lake Alchichica bacteria showed elongated and thin shapes whilst in Lake Maggiore the cells had a coccoid form according to the $\mathrm{W} / \mathrm{L}$ ratio (Tab. 3).

In Lake Maggiore bacteria cell volumes were significantly correlated with DO, SRP and DIN. In Lake Alchichica bacteria cell volume were significantly correlated only with DO and SRP. In both lakes there is no significant correlation between bacteria cell volume and temperature (Tab. 4).

\section{DISCUSSION}

In the temperate Lake Maggiore and in the tropical Lake Alchichica a parallel increase of cell size with depth was found during two seasonal cycles. One explanation of the larger bacteria found in the hypolimnion could be related to differences in community composition. In Lake Alchichica the bacterial composition in the anoxic hypolimnion is associated to denitrification process and sulphate reduction and may explain the larger size observed in this layer (Hernández-Avilés et al. 2010). Nevertheless no strong evidence has been published on the direct relation between the bacterial community composition and cell size. Studies of the phylogenetic composition of LNA and HNA have obtained conflicting results: some demonstrated that LNA bacteria are not substantially different from HNA bacteria in terms of composition (Bernard et al. 2000; Longnecker et al. 2005); conversely, others found that the phylogenetic composition of the two fractions differs (Zubkov et al. 2001). These results show that more studies are necessary before we can indicate the community composition as a cause of the difference in size along the vertical profile (Bouvier et al. 2007). Cell size polymorphism has been found to characterize some species, but adaptation to starvation, UVR or grazing can alter natural morphological characteristics (Bernard et al. 2000; Corno et al. 2009). Therefore, if there is a relation between bacterial cell size and phylogenetic composition,
Tab. 3. Mean Width-Length (W/L) ratio of bacterial cells indicating their morphology (near 1 circular shape, $<0.2$ elongated forms).

\begin{tabular}{lccc}
\hline & Year & $\begin{array}{c}\text { Epilimnion } \\
\text { W/L }\end{array}$ & $\begin{array}{c}\text { Hypolimnion } \\
\text { W/L }\end{array}$ \\
\hline L. Maggiore & 2006 & 0.67 & 0.71 \\
& 2007 & 0.69 & 0.66 \\
L. Alchichica & 2006 & 0.24 & 0.24 \\
& 2007 & 0.18 & 0.18 \\
\hline
\end{tabular}

Tab 4. Spearman rank correlation coefficients between bacterial volume $\left(\mu \mathrm{m}^{3}\right.$ cell $\left.^{-1}\right)$ and the four physicochemical parameters considered in Lake Maggiore and Lake Alchichica. Significant differences: $*=p<0.05, * *=p<0.01 ; * * *=p<0.001$; n.s. $=$ no significant difference $p>0.05$. Abbreviation as in Tab. 1 .

\begin{tabular}{lcccc}
\hline & Temperature & DO & PSR & DIN \\
L. Maggiore $(\mathrm{n}=50)$ & -0.02 (n.s.) & $-0.46^{* * *}$ & $0.28^{*}$ & $0.46^{* * *}$ \\
L. Alchichica $(\mathrm{n}=40)$ & -0.06 (n.s.) & $-0.39 * *$ & $0.32 *$ & 0.07 (n.s.)
\end{tabular}

it is not that simple to demonstrate and can vary greatly between ecosystems (Bouvier et al. 2007).

The absence of a correlation between temperature and bacterial size in Lake Maggiore and Lake Alchichica indicates that temperature cannot be assumed as a deterministic factor influencing the average larger size of bacteria in the hypolimnion, as previously hypothesized (Bertoni et al. 2010). The significant inverse correlation of bacterial size and oxygen indicates that smaller bacteria prevail in the epilimnetic layer, always well oxygenated in both lakes. Thus the relation cell-size/oxygen could be an indirect one, likely related to the smaller bacteria outcompeting the larger authotrophs in the more oxygenated epilimnion. But the interaction between bacteria and producers in the oxygenated epilimnion can also be not competitive. In a recent study, it has been found that the small cells are those which consume only the labile fraction of organic substrates, produced by algae, while the larger ones can also use more refractory sources of nutrients (Zubkov et al. 2004).

One common characteristic of Lake Maggiore and Lake Alchichica is their trophic state. According to their nutrient and chlorophyll- $a$ concentrations, both lakes are oligotrophic (Tab. 1). In general, oligotrophic conditions induce temporary or permanent bacterial adaptation characterized by decreased cellular volume (Schut et al. 1997). Therefore, in Lake Maggiore and Alchichica, picoplankton can constitute a large portion of the biomass and the productivity of the system. The dominance of picoplankton in oligotrophic systems (Callieri, and Stockner 2002) can also be explained by their high affinity for orthophosphate (Moutin et al. 2002) and their maximum cell specific Puptake rates. In Lake Alchichica, during mixing and early stratification, the concentrations of dissolved inorganic nitrogen (DIN) and soluble reactive phosphorus 
(SRP) are high, whilst during well-established and late stratification, nutrients are exhausted in the epilimnion and accumulated in the hypolimnion (Hernández-Avilés et al. 2010). In both lakes, SRP concentration in hypolimnion is significantly higher than in epilimnion as well as DIN. The significant correlations between cell volume and both SRP and DIN found in Lake Maggiore and SRP in Lake Alchichica indicate that in both lakes the limiting phosphorus can favor smaller cells, with a lower surface/volume ratio, present in the epilimnion, whereas the effect of nitrogen can be controversial. Conversely, in the hypolimnion, in absence of algal competition and nutrient limitation, the necessity to be small is not so compelling. Therefore, we might suggest that bacteria in the epilimnion are smaller than in the deeper layer to outcompete larger bacteria or even algae. Actually, in nutrient-limited food webs, the primary producers and the heterotrophic bacteria will act as competitors for the limiting nutrient (Olsen et al. 2002), the latter outcompeting the former (Vadstein 2000; Cotner, and Biddanta 2002).

The $\mathrm{W} / \mathrm{L}$ ratio of bacteria in Lake Maggiore is around 3 times higher than in Lake Alchichica (Tab. 3). In batch cultures growing exponentially, it has been found that under $\mathrm{C}$ and $\mathrm{P}$ limitation $\mathrm{W} / \mathrm{L}$ ratio increased, and at very low $\mathrm{W} / \mathrm{L}$ ratio the cells were $\mathrm{N}$-limited (Vrede et al. 2002). According to the $\mathrm{W} / \mathrm{L}$ found in the two lakes, we infer that bacterial growth in Lake Maggiore is limited by $\mathrm{P}$ and in Lake Alchichica by N. Indeed, also primary production in temperate lakes is P-limited while in tropical lakes is $\mathrm{N}$ limited (Lewis 2002, 2010) or co-limited by $\mathrm{N}$ and $\mathrm{P}$ (Hernández-Avilés et al. 2001). In Lake Alchichica, an alternation in nitrogen, phosphorus or both nutrients in limiting phytoplankton biomass has been experimentally found (Ramírez-Olvera et al. 2009).

Our hypothesis that bacterial size vertical distribution in Lake Maggiore and Lake Alchichica responds to the availability of nutrients in different layers is in accordance with the results obtained on the vertical variation of bacterial nucleic acid contents in the warm monomictic Lake Biwa (Nishimura et al. 2005). In this lake, during the stratification period an increment of the percentage of HNA and decrement of LNA bacteria with depth was found. Besides, the authors found a strong positive correlation between HNA and the dissolved inorganic phosphorus concentration. They concluded that LNA bacteria outcompete HNA and become an important component of the microbial loop in P-limited environments.

The presence of smaller bacteria in the superficial layers might also be related to the presence of labile compounds produced by algae. If the hypothesis formulated by Zubkov et al. (2004) is verified, the smaller LNA bacteria not only win the competition for $\mathrm{P}$ with algae, but they also take advantage directly from their competitors using the excreted substances they produce.
In conclusion, without excluding the important role of top-down control in the size composition of bacterial community, we found that the bottom-up control can affect bacterial size on a seasonal scale in oligotrophic temperate and tropical lakes.

\section{ACKNOWLEDGMENTS}

The research on Lake Alchichica was partially supported by DGAPA-UNAM PAPIIT IN207206-3, and PASPA DGAPA grants. Part of the data on Lake Maggiore were supported by the International Commission for the Protection of Italian-Swiss Waters (CIPAIS). We thank for field support Luis Oseguera, Laura Peralta (FES Iztacala, UNAM) and Mario Contesini (CNR ISE, Italy); for laboratory assistance Juan Antonio Arellano and Eunice González (FES Zaragoza, UNAM) and for providing nutrient data, Martín Merino and Sergio Castillo (ICMyL, UNAM) and the water chemistry laboratory of CNR ISE (Gabriele Tartari, Michela Rogora).

\section{REFERENCES}

Adame MF, Alcocer J, and Escobar E. 2008. Size-fractionated phytoplankton biomass and its implications for the dynamics of an oligotrophic tropical lake. Freshwater Biol. 53: 22-31.

Alcocer J, López Anaya DP, and Oseguera LA. 2007. Dinámica del carbono orgánico partículado en un lago tropical profundo. In: Hernández T.B., and C.G. Gaxiola (Eds), Carbono en ecosistemas acuáticos de México. Secretaría de Medio Ambiente y Recursos Naturales. Instituto Nacional de Ecología. México. 239-247.

Alcocer J, Lugo A, Escobar E, Sánchez MR, and Vilaclara G. 2000. Water column stratification and its implications in the tropical warm monomictic Lake Alchichica, Puebla, Mexico. Verh. int. Ver. Limnol. 27: 3166-3169.

Ambrosetti W, Barbanti L, and Sala N. 2003. Residence time and physical processes in lake. J. Limnol. 62: 1-15.

A.P.H.A. 1992. Standard methods for the examination of water and wastewater. Am. Publ. Health Ass. Washington.

Azam F, Fenchel T, Field GC, Grey JS, Meyer-Reil LA, and Thinstad F. 1983. The ecological role of water-column microbes in the sea. Mar Ecol. Prog. Ser. 10: 257-263.

Berdjeb L, Pollt T, Domaizon I, and Jacquet S. 2011. Effects of grazers and viruses on bacterial community structure and production in two contrasting trophic lakes. BMC Microb. 11: 1-18.

Bernard L, Courties C, Servais P, Troussellier M, Petit M, and Lebaron L. 2000. Relationships among bacterial cell size, productivity, and genetic diversity in aquatic environments using cell sorting and flow cytometry. Microb. Ecol. 40: 148-158.

Bertoni R, Piscia R, and Callieri C. 2004. Horizontal heterogeneity of seston, organic carbon and picoplankton in the photic zone of Lago Maggiore, Northern Italy. J. Limnol. 63: 244-249.

Bertoni R, Callieri C, Corno G, Rasconi S, CaravatiE, and Contesini M. 2010. Long-term trends of epilimnetic and hypolimnetic bacteria organic carbon in a deep 
holo-oligomictic lake. Hydrobiologia 644: 279-287.

Bouvier T, del Giorgio PA, and Gasol JM. 2007. A comparative study of cytometric characteristics of High and Low nucleicacid bacterioplankton cells from different aquatic ecosystems. Environ. Microbiol. 9: 2050-2066.

Button DK, Robertson BR, and Juttner F. 1996. Microflora of a subalpine lake: bacterial populations, size and DNA distributions, and their dependence on phosphate. FEMS Microbiol. Ecol. 21: 87-101.

Callieri C, and Stockner JG. 2002. Freshwater autotrophic picoplankton: a review. J. Limnol. 61(1): 1-14.

Corno G, Modenutti BE, Callieri C, Balseiro EG, Bertoni R, and Caravati E. 2009. Bacterial diversity and morphology in deep ultraoligotrophic Andean lakes: role UVR on vertical distribution. Limnol. Oceanogr. 54: 1098-1112.

Cotner J, and Biddanda BA. 2002. Small payers, large role: Microbial influence on biogeochemical process in pelagic aquatic ecosystems. Ecosystems 5: 105-121.

de Bernardi R, Calderoni A, and Mosello R. 1996. Environmental problems in Italian lakes, and lakes Maggiore and Orta as successful examples of correct management leading to restoration. Verh. int. Ver. Limnol. 26: 123-138.

Felip M, Andreatta S, Sommaruga R, Straskrábová V, and Catalan J. 2007. Suitability of flow cytometry for estimating bacterial biovolume in natural plankton samples: comparison with microscopy data. Appl. Environ. Microbiol. 73: 45084514.

Filonov A, Tereshchenko I, and Alcocer J. 2006. Dynamic response to mountain breeze circulation in Alchichica, a crater lake in Mexico. Geophysic Res. Lett. 33: 1-4.

Gasol JM, del Giorgio PA. 2000. Using flow cytometry for counting natural planktonic bacteria and understanding the structure of planktonic bacterial communities. Sci. Mar. 64: 192-224.

Gasol JM, del Giorgio PA, Massana R, and Duarte CM. 1995. Active versus inactive bacteria: size-dependence in coastal marine plankton community. Mar. Ecol. Prog. Ser. 128: 9197.

Gasol JM, Zweifel UL, Peters F, Fuhrman JA, and Hagström A. 1999. Significance of size and nucleic acid content heterogeneity as measured by flow cytometry in natural planktonic bacteria. Appl. Environ. Microbiol. 65: 4475-4483.

Hahn MW, and Höfle MG. 1999. Flagellate predation on a bacterial model community: Interplay of size-selective grazing, specific bacterial cell size, and bacterial community composition. Appl. Environ. Microbiol. 65: 4863-4872.

Hernández-Avilés JS, Macek M, Alcocer J, López-Trejo B, and Merino-Ibarra M. 2010. Procaryotic picoplankton dynamics in a warm-monomictic saline lake: temporal and spatial variation in structure and composition. J. Plankton Res. 32: 1301-1314.

Hernández-Avilés JS, Bernal-Brooks F, Velarde G, Ortiz D, Lind OT, and Dávalos-Lind L. 2001. The algal growth potential and algae growth-limiting nutrients for 30 of Mexico's lakes and reservoirs. Verh. int. Ver. Limnol. 2: 3583-3588.

Jürgens K, and Matz C. 2002. Predation as a shaping force for the phenotypic and genotypic composition of planktonic bacteria. Antonie Van Leeuwenhoek 81: 413-434.

Lebaron P, Servais P, Agogue H, Courties C, and Joux F. 2001.
Does the high nucleic acid content of individual bacterial cells allow us to discriminate between active cells and inactive cells in aquatic systems? Appl. Environ. Microbiol. 67: 1775-1782.

Lewis WM. 2002. Causes for the high frequency of nitrogen limitation in tropical lakes. Verh. int. Ver. Limnol. 28: 210213.

Lewis WM. 2010. Biogeochemistry of tropical lakes. Verh. int. Ver. Limnol. 30: 1595-1603.

Longnecker K, Sherr BF, and Sherr EB. 2005. Activity and phylogenetic diversity of bacterial cells with high and low nucleic acid content and electron transport system activity in an upwelling ecosystem. Appl. Environ. Microbiol. 71: 7737-7749.

Macek M, Alcocer JD, Lugo AV, Martínez-Pérez ME, Peralta L, and Vilaclara G. 2009. Long term picoplankton dynamics in a warm-monomictic, tropical high altitude lake. J. Limnol. 68: 183-192.

Moutin T, Thingstad TR, Van Wambeke F, Marie D, Slawyk G, Raimbault P, and Claustre H. 2002. Does competition for nanomolar phosphate supply explain the predominance of the cyanobacterium Synechococcus? Limnol. Oceanogr. 47:1562-1567.

Nishimura Y, Kim C, and Nagata T. 2005 Vertical and seasonal variations of bacterioplankton subgroups with different nucleic acid contents: possible regulation by phosphorus. Appl. Environ. Microbiol. 71: 5828-5836.

Olsen LM, Reinertsen H, and Vadstein O. 2002. Can phosphorus limitation inhibit dissolved organic carbon consumption in aquatic microbial food webs? A study of three food web structure in microcosms. Appl. Environ. Microbiol. 43: 353366.

Pernthaler J. 2005. Predation on prokaryotes in the water column and its ecological implications. Nature Rev. Microbiol. 3: 537-546.

Porter KG, and Feig YS. 1980. The use of DAPI for identifying and counting aquatic microflora. Limnol. Oceanogr. 25: 943-948

Posch T, Pernthaler J, Alfreider A, and Psenner R. 1997. Cellspecific respiratory activity of aquatic bacteria studied with the tetrazolium reduction method, Cyto-Clear slides, and image analysis. Appl. Environ. Microbiol. 63: 867-873.

Ramírez-Olvera MA, Alcocer J, Merino-Ibarra M, and Lugo A. 2009. Nutrient limitation in a tropical saline lake: a microcosm experiment. Hydrobiologia 626: 5-13.

Robertson BR, and Button DK. 1989. Characterizing aquatic bacteria according to population, cell size and apparent DNA content by flow cytometer. Cytometry 10: 70-76.

Schut F, Princess RA, and Gottschall JC. 1997. Oligotrophic and pelagic marine bacteria: facts and fiction. Aquat. Microb. Ecol. 12: 177-202.

Shapiro HM. 1995. Practical flow cytometry. Wiley-Liss, New York: $542 \mathrm{pp}$.

Sherr BF, and Sherr EB. 2000. Marine microbes: an overview. In: Kirchman D.L. (Ed.), Microbial ecology of the oceans. Wiley-Liss, New York. 13-46.

Simon M, Cho BC, and Azam F. 1992. Significance of bacterial biomass in lakes and the ocean: comparison to phytoplankton biomass and biogeochemical implications. Mar. Ecol. Prog. Ser., 86: 103-110. 
Stevenson LH. 1978. A case for bacterial dormancy in aquatic systems. Microb. Ecol. 4: 127-133.

Vadstein O. 2000. Heterotrophic, planktonic bacteria and cycling of phosphorus. Phosphorus requirements, competitive ability and food web interaction. Adv. Microb. Ecol. 16: 115167.

Vrede K, Heldal M, Norland S, and Bratbak G. 2002. Elemental composition $(\mathrm{C}, \mathrm{N}, \mathrm{P})$ and cell volume of exponentially growing and nutrient-limited bacterioplankton. Appl. Environ. Microbiol. 68: 2965-2971.

Wang Y, Hammes F, Boon N, Chami M, and Egli T. 2009. Isolation and characterization of low nucleic acid (LNA)-con- tent bacteria. ISME J 3:889-902.

Weinbauer M, and Höfle M. 1998. Size-specific mortality of lake bacterioplankton by natural virus communities. Aquat. Microb. Ecol. 15: 103-113.

Zubkov MV, Allen JI, and Fuchs BM. 2004. Coexistence of dominant groups in marine bacterioplankton community - a combination of experimental and modelling approach. J. Mar. Biol. Assoc. U.K. 84:519-529.

Zubkov MV, Fuchs BM, Burkill PH, and Amann R. 2001. Comparison of cellular and biomass specific activities of dominant bacterioplankton groups in stratified waters of the Celtic Sea. Appl. Environ. Microbiol. 67: 5210-5218. 